\title{
Grass fields as reservoirs for polyphagous predators (Arthropoda) of aphids (Homopt., Aphididae)
}

Article in Journal of Applied Entomology · August 2009

DOI: $10.1111 /$ j.1439-0418.1987.tb00547.x

CITATIONS

31

2 authors, including:

\section{Søren Toft}

Aarhus University

116 PUBLICATIONS 3,382 CITATIONS
READS

49

SEE PROFILE 
Sonderdruck aus Bd. 104 (1987), H. S, S. 461-473

Zeitschrift für angewandte Entomologie

VERLAG PAUL PAREY - SPITALERSTRASSE 12 - D-2000 HAMBURG 1 Alle Rechte, auch die der Übersetzung, des Nachdrucks, der photomechanischen Wiedergabe und Speicherung in Datenverarbeitungsanlagen, vorbebalten. $\varnothing 1987$ Verlag Paul Parey, Hamburg und Berlin

\title{
Grass fields as reservoirs for polyphagous predators (Arthropoda) of aphids (Homopt., Aphididae)
}

\author{
By EjgIL Gravesen and Søren Tofr
}

\begin{abstract}
In a 4 ha grass field in Denmark three separate plots of $15 \times 25 \mathrm{~m}$ were cultivated with barley. In each plot a central area of $5 \times 5 \mathrm{~m}$ were fenced off by a plastic barrier. Thus, each plot consisted of an unfenced area, accessible for predators immigrating from the grass field, and an unaccessible, fenced area. Numbers of polyphagous predators and aphids were recorded throughout the growing season. In the unfenced areas with high numbers of predators, aphid populations reached only one third the size in the fenced, predator-low areas.

June-numbers of several predator groups and species were negatively correlated to three measures of aphid population development. Also, carabids as a group and two carabid species showed an aggregative response to aphid densities. For comparison, predators were positively correlated with Collembola numbers in spring, and also showed an aggregative response to these.

The carabid species on grass fields responded differently to the creation of the barley plots. The numerical dominants mainly stayed in the grass field and colonized the barley plots only to moderate degrees. Some less abundant carabid species, however, showed high colonizing ability.

It is argued that, with further knowledge about the dynamics of colonization, an appropriate mosaic of grass and cereal fields might be devised which maximizes the beneficial effect of the grass field predator reservoir.
\end{abstract}

\section{Introduction}

Polyphagous predators may play an important role in the suppression of aphid outbreaks. Experiments in England (EDWARDS et al. 1979; SUNDERLAND et al. 1980) and Sweden (ChIverton 1986) have shown that partial exclusion of these predators can lead to large increases in aphid numbers.

Overwintering in field boundaries, grass banks or grass fields is important for many aphidophagous carabid beetles (SOTHERTON 1984, 1985) and undersowing cereals with grass favours the arthropod fauna. In a study by VICKERMAN (1978), about $70 \%$ more arthropods emerged the following spring from newly established grass fields, than from fields which were ploughed and cultivated after harvest.

U.S. Copyright Clearance Center Code Statement: 0044-2240/87/0405-0461 \$ 02.50/0

J. Appl. Ent. 104 (1987), 461-473

(C) 1987 Verlag Paul Parey, Hamburg und Berlin

ISSN 0044-2240 
PotTs and Vickerman (1974) drew attention to the faunal exchange between grass and cereal fields. In particular they stressed the role of the predators. They suggested that "much of the present stability of the cereal fauna may result from its association with the relatively stable and complex grassland fauna". We here report on an investigation designed to evaluate the potential of grasslands as reservoirs for polyphagous predators in areas with cereal grassland rotation. This has been carried out by cultivating three plots within a grass field. Each plot was sown with barley and contained a fenced-off area. Thus, each plot consisted of two parts, of which one was accessible for invasion by ground-moving predators, whereas the other was not. This was intended to mimic cereal fields adjacent to, and far away from grass fields, respectively. Evaluation is made by comparing both predator numbers and aphid population densities on either side of the dispersal barriers.

\section{Study area}

The study area was situated at Sdr. Felding in Western Jutland, Denmark. The research took place in a $6 \mathrm{~km}^{2}$ agricultural area, reclaimed gradually between 1900 and 1960 , and grown with cereals, sugar beet and grass. The soil is sandy moraine, which is typical for the western part of Jutland. Since the reclamation, 2- or 3-year grass fields have taken up $25-50 \%$ of the area. For the last twenty years, spring barley undersown with clover or ryegrass has covered between 25 and $50 \%$ of the area.

At least for the last ten years, it has not been necessary to use insecticides against aphids in the area, but in 1983 and 1984 10-15\% of the area was treated with Parathion against crane fly larvae.

The experiments were done in a 4 ha grass field. The humus content of the soil is $4.8 \%$, which is typical for soils partly grown with grass. The field was given both organic and artificial fertilizers.

The field is part of a 7-year rotation system, starting with grass in 1976-79, in 1980 it was grown with sugar beet, in 1981 spring barley undersown with rye grass, and finally in 1982 spring barley undersown with clover and grass. This clover-grass was maintained through 1983 and 1984 . In none of the years were any insecticides applied to the field.

\section{Methods}

\subsection{Experiment}

During a 5-day period, April 14 to 18 1984, three plots in the grass field were cultivated (fig. 1a). In the three plots, each $15 \times 25 \mathrm{~m}$ separated by a $25 \mathrm{~m}$ grass strip, the grass was either ploughed and harrowed, rotavated or only harrowed, respectively, before sowing barley cv. Georgie. Rotavation and harrowing were done twice to a depth of $5 \mathrm{~cm}$. The plots were supplied with artificial fertilizer before sowing barley mixed with rye grass. No pesticide treatment was done.

In the middle of each plot, a $5 \times 5 \mathrm{~m}$ plastic-barrier was erected $60 \mathrm{~cm}$ high and buried to a depth of $15 \mathrm{~cm}$. A half-meter zone on the outside of the barriers was kept free of plants, to reduce invasion of arthropods above the fence (EDwards et al. 1979).

Predator numbers were recorded by pitfall trapping, each trap consisting of double set of plastic beakers of $7 \mathrm{~cm}$ diameter, $9 \mathrm{~cm}$ deep, half filled with a $3 \%$ formaldehyde solution. In the cultivated plots, 5 traps were placed inside each of the central barriers and 8 traps were placed outside at different distances $(2,4$ and $8 \mathrm{~m}$ ) from the grass edge. Furthermore, 4 traps were placed in the grass field, two on each side of every plot. The traps were operated continuously and emptied weekly until the experiment terminated on August 17.

Distribution of the traps as well as a short-hand notation of different parts of the experimental area are given in fig. 1.

In addition to pitfall trapping, aphids were counted on straws. From each plot, 32 straws were collected, 16 from inside and 16 from outside the barriers, every week of the period when aphids were present. Within the barriers the straws were taken regularly from a $3 \times 3 \mathrm{~m}$ network, outside they were all taken $1 \mathrm{~m}$ from the barrier (fig. $1 \mathrm{~b}$ ). Collecting this way was done to minimize the effect of climatic differences, due to the possibie windbreak and microclimatic effects of the barriers (CHIVERTON 1986). 


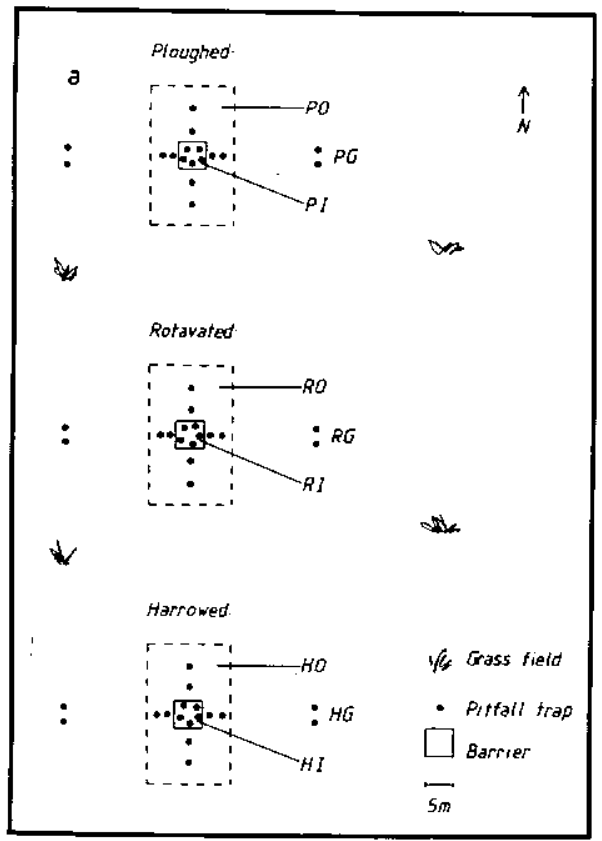

$b$

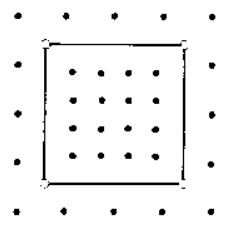

- Straw sample

Fig. 1. a: Design of experimental area, with a short-hand notation of different parts. b: Distribution of straw samples (dots) in relation to barriers. P: ploughed, $R$ : rotavated, $H$ : harrowed; I: inside barrier, O: outside barrier, G: grass field

The use of plastic barriers to confine or exclude surface-living polyphagous predators has proven successful in experiments at Rothamsted (EDWARDs et al. 1979) and at Uppsala (CHIVERTON 1986). Mark and recapture of beetles have shown that there was no more than $5 \%$ exchange of most species of carabids across such barriers (EDwarDs et al. 1979).

\subsection{Identification}

Arthropods were identified to order or lower group, carabid beetles to species.

As polyphagous predators we distinguished Opiliones, Lycosidae, other Araneae, Carabidae, Staphylinidae, Coleoptera larvae (mostly carabids and staphylinids), and Chilopoda. Chilopoda and Opiliones were caught in low numbers; they are treated only as part of the category "total polyphagous predators" (TPP), defined as the sum of the above mentioned groups. "Araneae" in the following means spiders without lycosids. The vast majority belong to the family Linyphiidae.

Rbopalosiphum padi (L.) was by far the most numerous aphid, and all aphid resules can be referred to this species.

\subsection{Statistics}

For statistical treatment of data we applied the SPSS-system. All parametric statistical tests were performed on $\log (x+1)$-transformed data.

As soil treatments were not replicated on separate plots, comparison of the differently treated fields is based on repeated sampling from the same plots ("pseudoreplication", cf. HurLBERT 1984), and the results can not without further qualification be interpreted as treatment effects. 


\section{Results}

\subsection{Differences between plots}

To see whether the grass field surrounding the experimental plots were homogenous with respect to the distribution of higher taxonomic groups, the grass trap catches were analysed by ANOVA with the results given in table $1 \mathrm{~A}$. Two groups of polyphagous predators, Lycosidae and Carabidae, showed significant main effects, carabids additionally a significant plot-season interaction. For carabids $P G$ had the highest and $H G$ the lowest catches, but the difference in the seasonal total was only $20 \%$. Coccinella larvae as well as several non-predatory groups likewise were heterogeneously distributed.

Similar tests were performed on the catches from the cultivated areas (table 1B). Here nearly all groups, in particular all the abundant polyphagous predator groups, showed highly significant main effects and interactions. The

Table 1. Significance levels for main effects and interactions from ANOVA-tests for faunistic differences between $A$ : traps in the grass field associated with the three different plots, B: traps in the three differently cultivated plots, and $\mathrm{C}$ : traps in fenced vs. unfenced areas of the cultivated plots. A comes from 2-way ANOVAs with plot and date as independent variables; B and C come from 3-way ANOVAs with plot, barrier (fenced/unfenced), and date as independent variables

\begin{tabular}{|c|c|c|c|c|c|c|c|c|}
\hline & \multicolumn{3}{|c|}{ A: grass fields } & \multicolumn{3}{|c|}{ B: cultivated plots } & \multicolumn{2}{|c|}{ C: cultivated plots } \\
\hline & $\begin{array}{l}\text { Plot } \\
\text { (P) }\end{array}$ & $\begin{array}{l}\text { Date } \\
\text { (D) }\end{array}$ & $\begin{array}{c}\mathrm{P} / \mathrm{D} \\
\text { Interaction }\end{array}$ & $\begin{array}{l}\text { Plot } \\
(\mathrm{P})\end{array}$ & $\begin{array}{l}\text { Date } \\
\text { (D) }\end{array}$ & $\underset{\text { Interaction }}{\mathrm{P} / \mathrm{D}}$ & $\begin{array}{c}\text { Barrier } \\
\text { (B) }\end{array}$ & $\underset{\text { Interaction }}{\mathrm{B} / \mathrm{D}}$ \\
\hline \multicolumn{9}{|c|}{ Polyphagous predators } \\
\hline Lycosidae & .001 & .001 & $\mathrm{~ns}$ & .065 & .001 & .001 & .001 & .001 \\
\hline Araneae & ns & .001 & $\mathrm{~ns}$ & .001 & .001 & .001 & .001 & .001 \\
\hline Carabidae & .049 & .001 & .013 & .001 & .001 & .001 & .001 & .001 \\
\hline Staphylinidae & $\mathrm{ns}$ & .001 & ns & .001 & .001 & .001 & .001 & .001 \\
\hline Coleoptera larvae & ns & .001 & .070 & .001 & .001 & .018 & .001 & .001 \\
\hline \multicolumn{9}{|c|}{ Specific aphid predators } \\
\hline Coccinellidae & $\mathrm{ns}$ & .019 & ns & ns & .065 & .013 & ns & ns \\
\hline Coccinella larvae & .014 & $\mathrm{~ns}$ & ns & .002 & .001 & .001 & ns & $\mathrm{ns}$ \\
\hline \multicolumn{9}{|c|}{ Other groups } \\
\hline Collembola & .030 & .001 & $\mathrm{~ns}$ & .035 & .001 & .001 & .001 & .001 \\
\hline Aphidoidea & .001 & .001 & .001 & .001 & .001 & .001 & .001 & .001 \\
\hline Thysanoptera & ns & ns & ns & ns & ns & ns & ns & ns \\
\hline Diptera & ns & .001 & $\mathrm{~ns}$ & $\mathrm{~ns}$ & .001 & .004 & .001 & .001 \\
\hline Tipulidae & .001 & .001 & .001 & .004 & .001 & .001 & .003 & .001 \\
\hline Tipulidae larvae & ns & .047 & ns & .049 & .001 & .003 & ns & ns \\
\hline Hymenoptera & .001 & .001 & .001 & .008 & .001 & .054 & ns & ns \\
\hline Silphidae & ns & .004 & $\mathrm{~ns}$ & ns & .001 & ns & .001 & .001 \\
\hline Other Coleoptera & ns & .009 & ns & ns & .001 & .005 & .001 & .019 \\
\hline Diplopoda & .001 & .001 & .001 & .001 & .028 & .004 & $\mathrm{~ns}$ & ns \\
\hline
\end{tabular}

contrast in the level of heterogeneity among the polyphagous predators between the grass field and cultivated areas is indicative of differential effects of the cultivation methods. Figure 2 compares the catches of the most abundant groups and carabid species on the areas.

Araneae and Coleoptera larvae showed higher catches on the $R$ and $H$ plots, Staphylinidae particularly on the $\mathrm{HO}$ area, while carabids abounded on 
the $\mathrm{PO}$ area. These results are in agreement with the idea that more superficial tillage practices will favour most animal groups with carabids as a well known exception: According to THIELE (1977) ploughing is not a particularly detrimental disturbance to carabids. Due to the heterogeneity of catches in the grass traps and lack of treatment replication, however, no definitive conclusions about specific effects of the cultivation systems can be made.
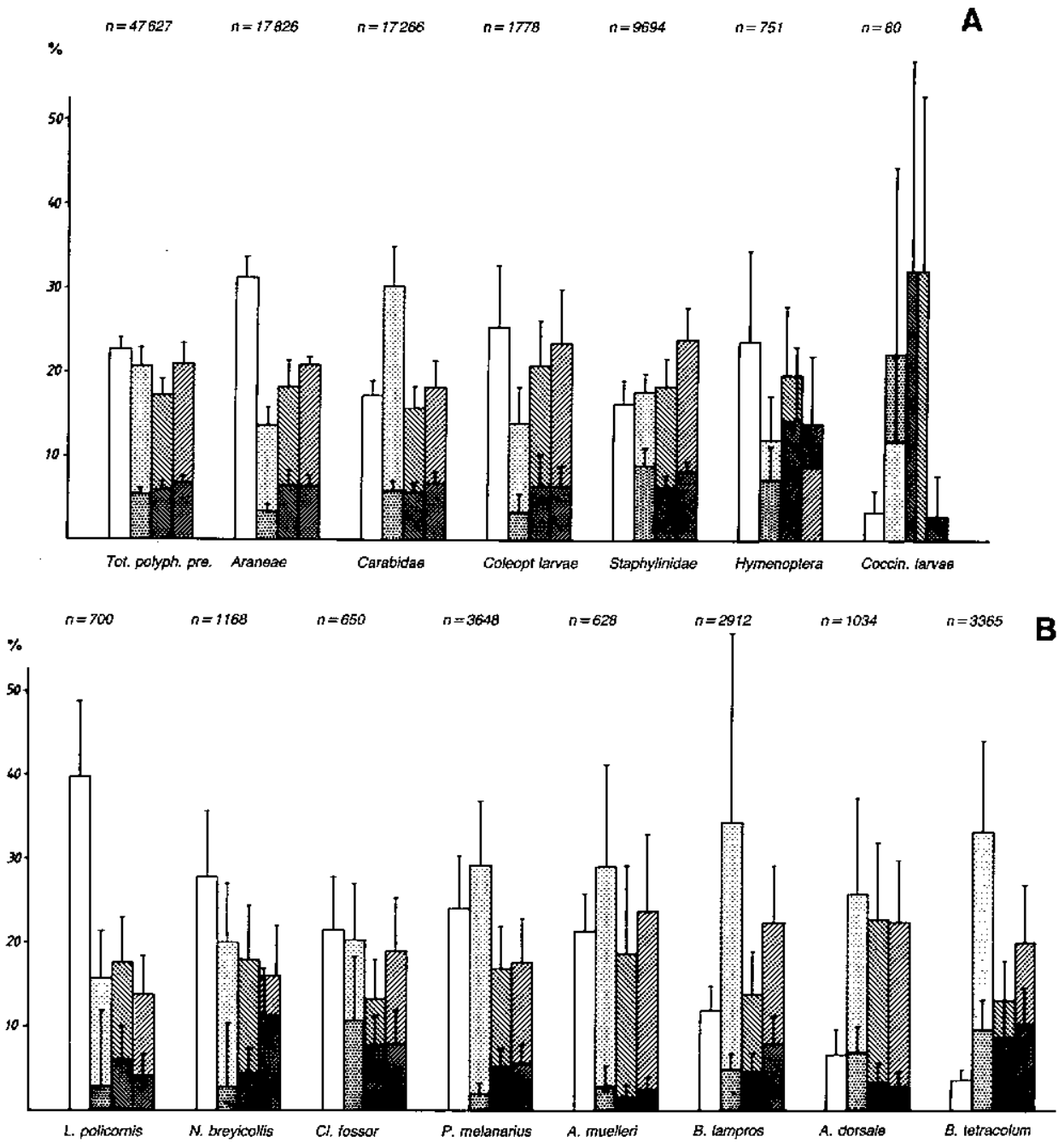

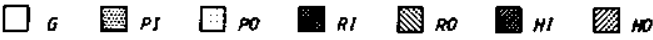

Fig. 2. Relative total seasonal catches per pitfall trap of main predator groups (A) and species of carabids $(B)$ in the different parts of the experimental field. Bars indicate one standard deviation. $n$ : total seasonal catch. For explanation of abbreviations see Fig. 1. The full names of carabid species are: Loricera pilicornis (F.), Nebria brevicollis (F.), Clivina fossor (L.), Pterosticus melanarius (Ill.), Agonum muelleri (Hbst.), Bembidion lampros (Hbst.), Agonum dorsale (Pont.), Bembidion tetracolum Say 


\subsection{Effect of the barriers}

The barriers were erected in order to create cultivated areas with particularly low numbers of predators compared with the areas into which predators could freely immigrate from the surrounding grass field. It appears from table $1 \mathrm{C}$ and fig. 2 that they were reasonably successful: For the ground-moving predator groups the traps in the fenced areas caught only about one third the numbers in the unfenced traps. In some carabid species, the difference was even greater (fig. 2B). For flying insects, like Hymenoptera and Thysanoptera, the barriers had no effect. The same applies to Coccinella, both larvae and adults, that also reach the areas in the first place by flight. Diptera were greatly affected by the barriers probably because most specimen caught in pitfall traps are small surface-active forms.

Collembola (fig. 3, table 1C) occurred in much higher numbers outside the barriers, indicating immigration from the grass field also in this group.

Aphids, however, showed quite the opposite pattern (fig. 3). In all three plots their numbers were not only significantly (table 1C), but also much higher in the fenced areas almost until the end of the season when populations crashed. This difference was revealed by both types of aphid sampling, pitfall traps and straw counts.

The catches of ground-moving predators in the fenced areas must represent mainly the fauna surviving the cultivation treatments. The differences between catches in fenced and unfenced parts of the plots must then be due to predators invading from the grass field. As this difference is substantial we conclude that proximity to a grass field means a significant increase in predator load, due to immigration. Quantitatively the increase was about 3-fold in the present situation, judged from mean weekly catches averaged over the whole trapping period (cf. fig. 2 and 3).

As Edwards et al. (1979), Declerce and Pietraszko (1983), and ChiverTON (1986) we interpret the differences in aphid numbers between fenced and unfenced areas as effects of the differences in predator load. Thus, proximity to a grass field may reduce aphid pest population peaks considerably, due to immigrating predators. The following section gives further justification for this interpretation.

\subsection{Aphid-predator relations}

Aphids $(R h$. padi) immigrated into the area during the month of June. They increased in numbers through July. In the straw counts they reached peak numbers between July 14 to 31 . In the pitfall catches the peaks came one or two weeks later (fig. 3). WikTELIUS and Eквом (1985) noted a one week difference in the peaks, using the same two methods, of the same species in Sweden.

There was a good correlation between the height of the peaks in the six areas as revealed by the two collecting methods (Spearman rank correlation, $\mathrm{r}_{\mathrm{s}}=.99, \mathrm{p}<.001$ ). Aphid numbers were considerably higher on the ploughed plot than on the other two plots (fig. 3). Also, the peaks came earlier in this plot. A tendential relationship that early peaks were high and late peaks small, comparatively, could not be statistically verified because of too many ties and small sample size $(\mathrm{n}=6)$.

Right from the beginning of the aphid season there were significant differences between aphid numbers in fenced and unfenced areas (pairwise 

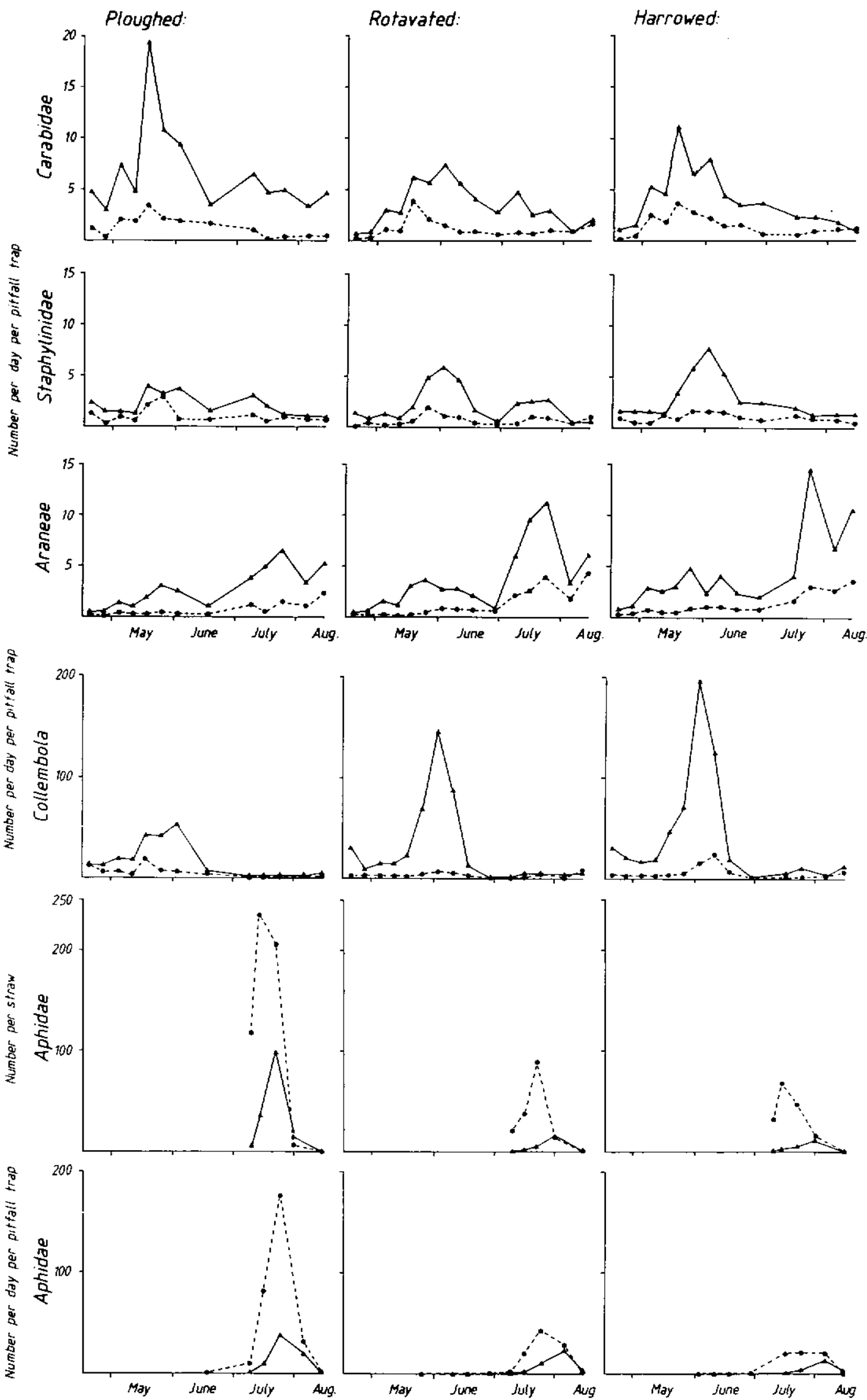

Fig. 3. Seasonal variation in catches of selected groups in areas outside (full line) and inside (broken line) the barriers of each experimental plot 
Mann-Whitney-tests for each date). This is consistent with the idea (EDwARDS et al. 1979; SUNDERLAND and VICKERMAN 1980) that the main importance of polyphagous predators as aphid predators lies in their predation at the time the aphids arrive and still are low in numbers.

As differences between the areas are (and are expected to be) created at a time when aphids are too low in numbers to be adequately recorded and statistically tested, it is difficult to distinguish the situation from one of differential colonization, for example due to the plastic barriers rather than predation. We here rely on the assumption that aphids in the present study behaved to our barriers as they did to those of EDwarDs et al. (1979) and ChIVERTON (1986). Our aphids were conspecific with those of the latter study, but not of the former. These authors found a differential effect of barriers erected at different times before the arrival of aphids, so only predators were manipulated differentially.

Further arguments in favour of the predation hypothesis can be found in the following correlations between aphid and predator numbers on the six cultivated areas (table 2). All correlations have mean monthly-average catches in pitfall traps in June as one variable and aphid numbers expressed in one of three different ways (see legend) as the other.

Table 2. Correlation coefficients and significance levels for double-log regressions of mean aphid and Collembola numbers and mean predator numbers in June on the six cultivated areas ( 3 plots, each with a fenced and unfenced area, i.e. $\mathrm{n}=6$ ). For aphids, three separate regression are shown, based on 1) seasonal average numbers per trap-week, 2) peak number per trap-week, and 3) peak number per straw. For Collembola the average of the trapping period 18. IV-23. VI is used

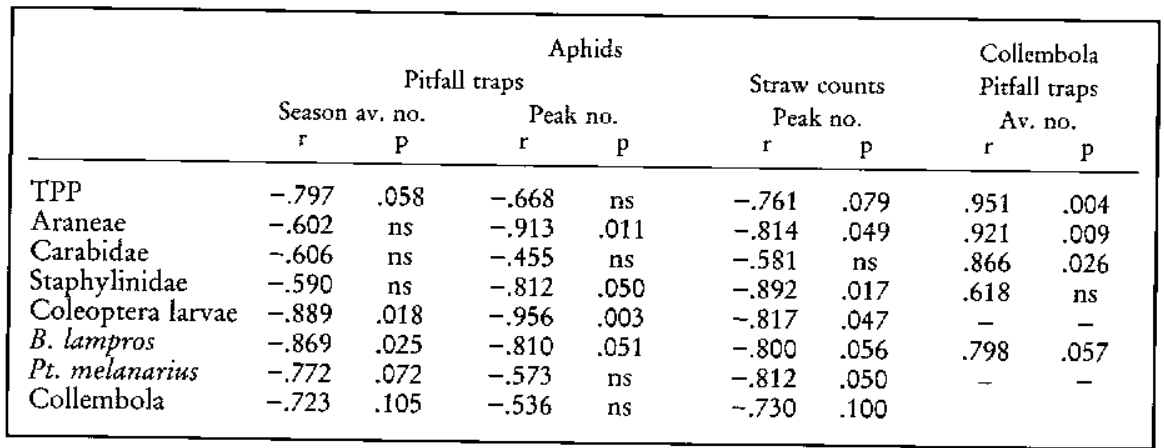

The reason for choosing June numbers of predators is that pitfall catches at this time can be taken to reflect the "effective abundance" (DEN BOER 1977; LUFF 1982) at the critical time of aphid arrival. Though not all correlations are significant, which is not unexpected in view of the fact that they contain only six data points each, it is noted that most are truly or at least marginally significant, and all are negative, i.e. showing the same trend. Carabids as a group show no significant correlations, but two species do so by themselves. Three other abundant species, $A$. dorsale, B. tetracolum and $N$. brevicollis, were tested but revealed no significant correlations.

Thus, areas with high numbers of predators in June produce lower populations of aphids later in the season. However, at the time of aphid abundance, aphids may constitute an important food base of the predators. In that case we would expect the predators to aggregate in areas with high aphid density (cf. 


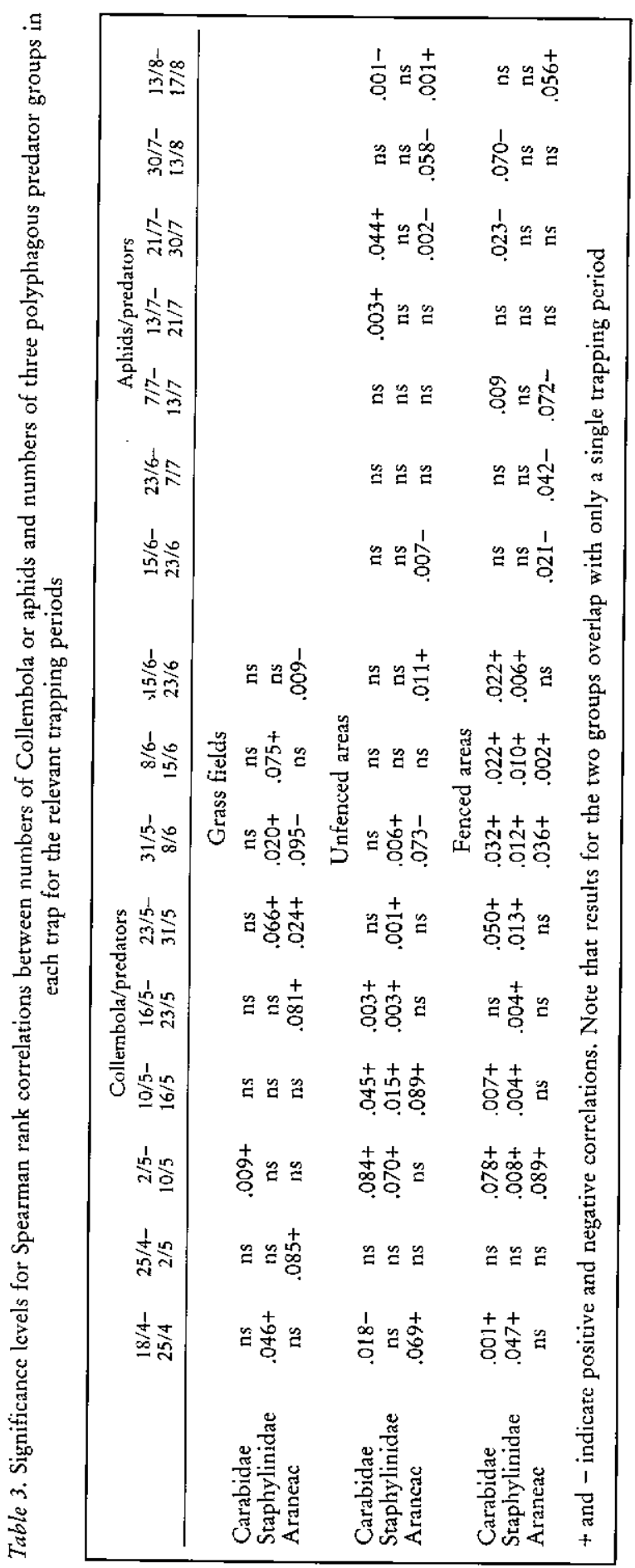


BRYAN and WRATTEN 1984). Thus, positive correlations between the number of aphids and number of predators caught in each trap during a trapping period may reveal which groups show this response. Due to the above correlations, these should be performed preferably on each area separately; however, due to the low sample size then, traps have been pooled so that Spearman rank correlations have been made on data from fenced and unfenced areas, respectively (table 3 ). In the unfenced areas carabids as a group showed significant positive aggregation on two dates at the second half of July, i.e. at the aphid peak; in the fenced areas all correlations were negative. Among the carabid species, Pt. melanarius and Calatbus fuscipes (Gz.) each showed positive aggregation at a single data on unfenced areas, while two significant correlations for $P_{t}$. melanarius in the fenced areas were negative. The reasons for these patterns are obscure. L. pilicornis, A. dorsale, $N$. brevicollis and $H$. rufipes were tested too, but they showed no significant correlations.

\subsection{Collembola - predator-aphid relations}

Of the Collembola caught Isotoma viridis Bourl. made up about $90 \%$, Sminthurus viridis (Lubbock) most of the remaining.

As noted earlier, collembolans showed high activity on unfenced barley areas in the spring months (fig. 3), but they nearly disappeared at the end of June. According to table 2, there are significant positive correlations between the catches of Collembola and several predator groups on the six cultivated areas. If we further correlate Collembola and predator numbers in each trap (traps in grass, fenced, resp. unfenced areas pooled) we find positive correlations on several single dates (table 3 ), indicating that predators in spring aggregated in areas of high abundance of Collembola. PotTs and VICKERMAN (1974) also found a positive correlation between Collembola and predatory beetles.

Polyphagous predators of cereal fields are known to prey extensively on Collembola (SunderLand 1975; Sunderland et al. 1986; NyFfeler 1982). The correlations given above may indicate that Collembola forms a very important food source for the predators in early spring. They further indicate that the distribution of the predators in late spring to a large extent may have been determined by an aggregative response to collembolan densities. If so, this is the distribution of the predators at the time the aphids arrive to the fields. Thus, the intensity of the early predation on aphids might be indirectly determined by the distribution of Collembola. Actually, correlations between spring catches of Collembola and subsequent aphid populations are all negative, as expected (table 2), but not significantly, though two of them are marginally significant (consider again low sample size, $n=6$ ). Also aggregation at high densities of Collembola, and probably other prey types as well, may account for the mainly negative correlations with aphids (table 3 ), at least on the early dates.

\subsection{Differential invasion of carabid species}

Figure $2 \mathrm{~B}$ shows the relative catches of the most numerous carabid species on the different parts of the study area. It appears that some species (those to the left in the figure) show high abundance on the grass field and more moderate abundance on the cultivated areas. The species to the right in the figure are abundant on the cultivated areas but comparatively rare on the grass field. 
Thus, there seems to be no direct positive relationship between a species' abundance in the grass field and its abundance in the adjacent field.

Using data for the twelve most abundant species we have made Sperman rank correlations between numbers in the grass field traps and numbers in the barley field traps, fenced and unfenced areas separately, for each of the three plots (table 4). Though all correlations are positive only two are significant. If carabids invade the unfenced barley fields in numbers proportional to their abundance in the grass field, we should find a positive correlation.

No unfenced area shows a significant correlation, which means that immigration is not proportional to grass field abundance. However, two of the fenced areas, the rotavated and the harrowed ones, showed significant, positive correlations. As there is little immigration into the fenced areas, these findings need a different explanation. The most straight forward one is that the two methods of soil treatment which are generally believed to be the least detrimental, have left the species composition on the plots relatively undisturbed. Ploughing, on the other hand, may have incurred a differential mortality on the species.

These results thus indicate that soil treatments leave the carabid faunal composition relatively unaffected, whereas subsequent invasion brings a clear modification. The most numerous species in the grass field, $L$. pilicornis, $N$. brevicollis and $C$. fossor, seem to be poor invaders, whereas other species like $B$. lampros, $B$. tetracolum and $A$. dorsale, have a high potential for colonizing newly cultivated fields, Pt. melanarius and A. muelleri are intermediate (fig. 2B).

Thus the change of crop from cereal to grass, and vice versa, prompts changes in the direction of faunal development, favouring different sets of species.

\section{Discussion}

It is concluded from the present investigation that a cereal field may benefit greatly by adjascence to a grass field by way of increased predator load due to immigration. Though grass fields seemingly develop a fauna of their own, which do not colonize cereal field to important extents, they also contain populations of several species of carabids that abundantly colonize cereal fields. These colonizing species are all known to be important aphid predators (Sunderland 1975; Crook and Sunderland 1984), and the beneficial effects are revealed by considerable reductions in aphid populations.

It remains to be established how far into a cereal field the aphid-reducing effect of the grass field can be observed. Also, the importance of the size of the grass field for the intensity of colonization should be investigated. Given such 
data it should be possible to design an "optimal mosaic" of grass and cereal fields, which takes maximal advantage of the predator-pool effect of the grass fields. In the area of this study, farmers may already unconsciously be taking advantage of the high proportion of grass fields (25-50\% by area). As noted earlier, no insecticide spraying against aphids have been necessary for at least ten years.

Thus, besides use of reduced tillage practices, and creation of grass strips along field margins and hedges, design of field mosaics on single properties or larger areas, may be an additional fruitful and realistic way of "manipulating" predator populations for productive and environmental benefits.

It will be important to know more about the extent to which the cereal species like $A$. dorsale, $B$. lampros, and $B$. tetracolum actually use the grass fields. They are presently known as important hibernation refuges (SorHERTON 1984, 1985; WALLIN 1985). However, the fact that grass fields build up a carabid fauna which is distinct in composition from the cereal fauna, though incorporating the cereal dominants, does not exclude the possibility that the cereal species themselves find increased opportunities for population increase, due to reduced mechanical disturbance. In the rotational system used in our study area the beetles may have 2-4 successive breeding seasons in the same field without serious habitat disturbances. Thus, grass fields may have an additional function as true predator recruitment areas.

\section{Zusammenfassung}

Wiesen als Reservoire für polyphage Prädatoren (Arthropoda) von Blattläusen (Homopt., Apbididae)

Auf einem 4 ha großen Grasfeld in Dänemark wurden 3 verschiedene $15 \times 25 \mathrm{~m}$ umfassende Parzellen mit Gerste bepflanzt. In der Mitte jeder Parzelle wurden $5 \times 5 \mathrm{~m}$ große Stücke mit Plastik eingezäunt. Auf diese Wejse bestand jede Parzelle aus einem uneingezäunten Gebiet mit Zugang für Prädatoren vom umliegenden Gras und einem unzugänglichen eingezäunten Gebiet. Die Anzahl polyphager Prädatoren und Blattläuse wurde während der Wachstumsperiode registriert. In den uneingezäunten Gebieten mit einer hohen Anzahl von Prädatoren erreichten die Blattlauspopulationen nur $1 / 3$ der Anzahl in den eingezäunten Gebieten mit wenigen Prädatoren.

Die Juni-Zahlen einiger Prädatorengruppen und Arten wiesen bei 3 Messungen eine negative Korrelation zu der Entwicklung der Blattlauspopulationen auf. Laufkäfer als Gruppe und 2 Laufkäferarten zeigten aggregative Reaktionen auf die Dichte der Blattläuse. Im Vergleich hierzu waren Prädatoren mit den Collembolen im Frühjahr positiv korreliert und zeigten aggregative Reaktionen zu diesen.

Die Laufkäferarten des Grasfeldes reagierten unterschiedlich auf die Anlage der Gerstenfelder. Die numerischen Dominanten verblieben hauptsächlich auf dem Grasfeld und besiedelten die Gerstenfelder nur in mäßigem Grad. Einige weniger zahlreiche Laufkäferarten zeigten dagegen große Besiedlungsfähigkeit.

Es wird angenommen, daß mit weiterer Kenntnis der Besiedlungsdynamik ein passendes Mosaik von Gras- und Getreidefeldern erdacht werden könnte, welches den Nützlichkeitseffekt des Prädatorreservoirs der Wiesenflächen vergrößert.

\section{References}

BRYAN, K. M.; WRATTEN, S. D., 1984: The response of polyphagous predators to prey spatial heterogeneity: Aggregation by carabid and staphylinid beetles to their cereal aphid prey. Ecol. Ent. 9, 251-259.

Chiverton, P. A., 1986: Predator density manipulation and its effects on populations of Rhopalosiphum padi (Hom.: Aphididae) in spring barley. Ann. appl. Biol. 109, 49-60.

Crook, N. E.; SunderLand, K. D., 1984: Detection of aphid remains in predatory insects and spiders by ELISA. Ann. appi. Biol. 105, 413-422. 
Declerco, R.; Pietraszko, R., 1983: Epigeal arthropods in relation to predation of cereal aphids. In: Cavalloro, R. (ed.): Aphid antagonists. A. A. Balkema, Rotterdam, pp. 88-92. BOER, P. J. DEN, 1977: Dispersal power and survival. Carabids in a cultivated countryside. Miscell. papers Landb. Hogeschool Wageningen 14. Wageningen: Veenman and $\mathrm{Zn.} \mathrm{B.} \mathrm{V.}$

EDwARDS, C. A.; SUNDERLAND, K. D.; GEORGE, K. S., 1979: Studies on polyphagous predators of cereal aphids. J. appl. Ecol. 16, 811-823.

Hurlbert, S. H., 1984: Pseudoreplication and the design of ecological field experiments. Ecol. Monogr. 54, 187-211.

Luff, M. L., 1982: Population dynamics of Carabidae. Ann. appl. Biol. 101, 164-170.

NyFFELER, M., 1982: Field studies on the ecological role of the spiders as insect predators in agroecosystems (abandoned grassland, meadows and cereal fields). $\mathrm{Ph}$. D. thesis, Swiss Federal Institute of Technology, Zürich.

PotTs, G. R.; Vickerman, G. P., 1974: Studies on the cereal ecosystem. Adv, Ecol. Res. 8, 107-197.

SOTHERTON, N. W., 1984: The distribution and abundance of predatory arthropods overwintering on farmland. Ann. appl. Biol. 105, 423-429.

- 1985: The distribution and abundance of predatory Coleoptera overwintering in field boundaries. Ann. appl. Biol. 106, 17-21.

SunderLand, K. D., 1975: The diet of some predatory arthropods in cereal crops. J. appl. Ecol. $12,507-515$.

Sunderland, K. D.; Fraser, A. M.; Dixon, A. F. G., 1986: Distribution of linyphiid spiders in relation to capture of prey in cereal fields. Pedobiologia 29, 367-375.

SunderLand, K. D.; STACEY, D. L.; EDwards, C. A., 1980: The role of polyphagous predators in limiting the increase of cereal aphids in winter wheat. Bulletin SROP/WPRS III/4, 85-91.

Sunderland, K. D.; Vickerman, G. P., 1980: Aphid feeding by some polyphagous predators in relation to aphid density in cereal fields. J. Anim. Ecol. 17, 389-396.

Thiele, H.-U., 1977: Carabid beetles in their environment. A study on habitat selection by adaptation in physiology and behaviour. Berlin: Springer-Verlag.

Vickerman, G. P., 1978: The arthropod fauna of undersown grass and cereal fields. Scient. Proc. Royal Dublin Soc. (A) 6, 273-283.

WALLIN, H., 1985: Spatial and temporal distribution of some abundant carabid beetles (Coleoptera: Carabidae) in cereal fields and adjascent habitats. Pedobiologia 28, 19-34.

WrkteLius, S.; Eквом, B. S., 1985: Aphids in spring sown cereals in central Sweden. Abundance and distribution 1980-1983. Z. ang. Ent. 100, 8-16.

Authors' address: SøREN TOFT and EJGIL GRAvesen, Zoological Laboratory, University of Aarhus, DK-8000 Aarhus C, Denmark 